\title{
Corrigendum
}

\section{Corrigendum to: 'Ecological succession of zooplankton species in a temporary river in a semi arid region of Brazil' [Braz. J. Biol. Sci. (2014), vol. 1, no. 2, p. 51-58]}

\section{Maria Cristina Crispim*', Ronilson José da $\mathbf{P a z}^{2}$ and Takako Watanabe ${ }^{1}$}

${ }^{1}$ Universidade Federal da Paraíba (UFPB), Centro de Ciências Exatas e da Natureza, Departamento de Sistemática e Ecologia, CEP 58051-900, João Pessoa, PB, Brazil. *E-mail: mccrispim@hotmail.com.

2Instituto Brasileiro do Meio Ambiente e dos Recursos Naturais Renováveis (IBAMA), Caixa Postal 5063, CEP 58051-900, João Pessoa, PB, Brazil. E-mail: ronilson.paz@gmail.com.

The first author reports an error in the original version of this article. There is a paragraph repeated on page 56 of the article.

This error has now been corrected in the PDF version of the article.

The Editor-in-Chief would like to apologize for any inconvenience caused.
Received

November 8, 2016

Accepted

November 9, 2016

Released

December 31, 2016

Open Acess Full Text Article

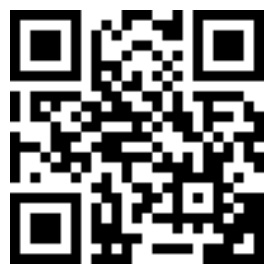

ORCIID

(D) 0000-0002-4414-2989 Maria Cristina Crispim

(D) 0000-0002-4990-4495

Ronilson José da Paz

D 0000-0003-0861-9839

Takako Watanabe 